Resenhas | Book Reviews

\title{
NAHUM-CLAUDEL, Chloe. Vital diplomacy: the ritual everyday on a dammed river in Amazonia. New York: Berghanh, 2018. $302 \mathrm{p}$.
}

Felipe Vander Velden*

*Universidade Federal de São Carlos - São Carlos, SP, Brasil

felipevelden@yahoo.com.br

https://orcid.org/0000-0002-5684-1250 
We know about dams because we too build dams for Yanwka. Discurso do líder Halataikwa Enawenê Nawê (p. 226)

Em tempos em que o país discute, enquanto sofre amargamente, os muitos efeitos trágicos e perversos de diferentes qualidades de barragens (Belo Monte, Santo Antônio, Mariana, Brumadinho...), a sensível etnografia de Chloe Nahum-Claudel entre os Enawenê-Nawê, povo de língua Arawak no noroeste do Mato Grosso, é mais do que oportuna. O absurdo representado pelos Enawenê, na vinheta que abre o livro, comprando três toneladas de peixes congelados de viveiros (iñoti kohase, "foreign fish") na cidade de Juína para remediar sua carência - porque os animais, fundamentais para o clímax de seu ciclo ritual anual não vieram naquele abril de 2009 - provocada pelo barramento do rio Juruena se soma a outros muitos absurdos que compõem a história do represamento de rios e rejeitos no Brasil.

Seres humanos interrompem artificialmente cursos d'água há milênios; nas terras baixas sul-americanas a construção de elaboradas estruturas para a coleta de peixes em maior escala é comum, como demonstram os casos mais conhecidos no alto rio Negro (Cabalzar, 2005), entre os Kaingang no sul (Mota; Noelli; Silva, 1996) e entre os próprios Enawenê-Nawê. Todavia, o contraste entre essas modestas barragens indígenas, feitas de madeira e amarradas com cipó, e as monstruosas megaconstruções de concreto e aço desses estranhos estrangeiros (iñoti), os "brancos", torna-se gritante pelo fato - uma espécie de equívoco pré-fabricado - de que uma mesma palavra designa, nas línguas portuguesa e inglesa, ambos os tipos de artefatos: barragem (dam). O contraste é ainda mais nítido quando se percebe que as grandes corporações que erguem tais obras são, ao mesmo tempo, o problema e a solução: em 2009 o peixe criado foi adquirido com dinheiro das compensações pagas aos Enawenê pelos impactos da hidrelétrica em seus rios e terras (p. 4); em 2019 o rompimento de uma represa de rejeitos de mineração da Vale mata trezentas pessoas e causa danos materiais e ambientais irreparáveis, mas a empresa é a garantia de sobrevivência de seus mais de 110 mil empregados apenas no Brasil. Armadilhas (de outro tipo) do capitalismo avançado que torna opaca a distinção entre mocinho e bandido, convidando-nos a dormir cotidianamente com o inimigo. 
Nesse cenário catastrófico - embora, da mesma forma, prenhe de novidades e potencialidades - situa-se esta etnografia do maior ritual do ciclo anual de festividades Enawenê-Nawê, o Yankwa, destinado a conservar a saúde e a prosperidade deste povo (p. 6), e que forma parte de uma espetacular vida cerimonial que se desenrola por todo o ano e solicita, como explicação, a aparente contradição do título da obra: um "cotidiano ritual" (ritual everyday). Seu foco está, com diz a autora, no "trabalho envolvido em sustentar uma vida ritual permanente" (p. 8, tradução minha), ritual que se busca entender aqui como um "processo" holístico, ao mesmo tempo econômico, social, cosmológico e político. Por ser assim, argumenta Nahum-Claudel, o Yankwa de certo modo "vaza" da aldeia Enawenê para os domínios que a circundam e ameaçam comprimi-la: se ele funciona, tradicionalmente, como o grande operador das relações entre os Enawenê e distintos tipos de outros - afins, espíritos, estrangeiros -, hoje este projeto de "diplomacia vital" (vital diplomacy) assume contornos crescentemente dramáticos porque é readequado para estruturar relações com novos tipos de alteridade, talvez mais ameaçadoras que as anteriores (como percebeu argutamente Davi Kopenawa, por exemplo) - os governos, o banqueiro, o minerador, o empresário.

Uma longa e densa introdução, seguida por cinco capítulos (divididos em duas partes), desenvolvem essa associação entre ritual e diplomacia, apostando em suas interpenetrações, ou na leitura de um conceito pelo prisma do outro, provocando uma radical alteração em ambos. Ademais, posiciona-se essa associação não apenas nos quadros da etnologia americanista como também na violenta história colonial dos Enawenê-Nawê e nos constantes ajustes que permitem a essa sociedade adaptar-se às intensas e extensas transformações que seu mundo atualmente enfrenta.

Este é, portanto, um livro sobre ritual, ou sobre um ritual específico, mas de enorme consequências para os Enawenê-Nawê, uma vez que o Yankwa é um rito de construção de mundo em que todos os domínios do cosmos, simbólicos e materiais, práticos e semióticos, desse grupo indígena colocam-se em movimento: um fato social total, em suma. E são articulados por meio da diplomacia, essa arte de reconhecer o outro, e ao mesmo tempo ser reconhecido por ele. Com isso, Nahum-Claudel busca compreender "modos ritualizados de gerar e reconciliar diferenças" (p. 20, tradução minha). E, ao inserir tal reflexão sobre os Enawenê-Nawê na etnologia americanista, a autora sugere, provocativamente, 
uma revisão do modelo geral da ontologia predatória amazônica, seguindo os passos críticos de Stephen Hugh-Jones em sua leitura do perspectivismo e do animismo em sua aplicação acrítica e descontrolada. Um dos contrastes mais interessantes, sugeridos pelos Enawenê e pela leitura que deles a autora nos propicia, é aquele entre sociedades que dependem da caça ou predação terrestre de animais (carne) e aquelas que tiram seu sustento basicamente da pesca e dos peixes, associadas com a agricultura ("fisher-agricultural societies").

Ao que parece, essa oposição - erigida por meio da atenção às relações com seres não humanos que chamamos animais - alinha-se a outras diferenças que se apresentam em contextos etnográficos clássicos que vêm, de certa forma, desafiando o modelo perspectivista, a saber, o alto rio Negro e o alto Xingu. Muito há de ser feito, ainda, para explorar os rendimentos teóricos sugeridos por essas sociocosmologias alternativas - por exemplo, sua ênfase na produção, na fertilidade e na abundância, em contraste com a economia de escassez permanente que parece caracterizar as sociedades predatórias de caçadores; apenas gostaria de pontuar que esse contraste, embora saliente, talvez tenha de ser matizado em nome de um conjunto de formas transicionais entre duas distintas modalidades de relação com animais, a cinegética e a piscatória. Os Karitiana, por exemplo, entre os quais trabalho, dependem tanto da pesca quanto da caça, não reduzindo uma à outra nem em termos de práticas nem quanto aos desdobramentos cosmológicos. Não é fortuito, penso, que os Enawenê-Nawê estejam situados, precisamente, nesta ampla zona de transição entre a Amazônia e o Brasil central, que vai aproximadamente dos Karajá até Rondônia, passando pelo Xingu: "espremida" entre dois modelos - o clássico amazônico (de Rivière e Overing e Viveiros de Castro) e o (não tão) clássico centro-brasileiro - essa área, já nos advertia Lévi-Strauss (1975), promete muito em termos do conhecimento das ontologias e sociocosmologias ameríndias, e devemos louvar mais essa contribuição, de Nahum-Claudel, no rumo de sua melhor compreensão.

Há muito mais aqui, obviamente, nessa rica, profunda e detalhada etnografia (o capítulo 3, por exemplo, dedica 30 páginas a apenas 48 horas!) da espetacular vida cerimonial e da diplomacia cósmica dos Enawenê-Nawê: os laços simbólicos e práticos entre a pesca e a agricultura, a estruturação do espaço e do som na performance ritual, a celebração da produtividade e da abundância, o potencial civilizatório e curativo da cozinha e da abstinência... e as respostas 
indígenas aos projetos de desenvolvimento, especialmente hidrelétricos. Essa aparentemente estranha combinação de objetivos "etnológicos" e "indigenistas" confere força adicional ao trabalho, que, ao investigar tanto a microdiplomacia cotidiana com outros invisíveis (os Yakairiti) quanto as relações exteriores com governos e poderosas empresas, não se limita a uma etnografia de um putativo povo indígena pré-contato, mas insere esse pequeno grupo, suas reflexões, seus dilemas, suas derrotas e (sobretudo) suas vitórias em um contexto de empreendimentos com terríveis consequências tanto para o Brasil como para o mundo: Balbina, Santo Antônio, Belo Monte, Mariana, Brumadinho. Tal como percebem a autora e os Enawenê ao final do livro (p. 251), dinheiro há de sobra para pagar, entre outras coisas, a ausência de participação política.

\section{Referências}

CABALZAR, A. Peixe e gente no alto rio Tiquié: conhecimentos Tukano e Tuyuka, ictiologia, etnologia. São Paulo: Instituto Socioambiental, 2005.

LÉVI-STRAUSS, C. A noção de arcaísmo em etnologia. In: LÉVI-STRAUSS, C. Antropologia estrutural. Rio de Janeiro: Tempo Brasileiro, 1975. p. 121-139.

MOTA, L. T.; NOELLI, F.; SILVA, F. Pãri: armadilha de pesca utilizada pelos índios Kaingang no sul do Brasil. Universidade e Sociedade, n. 16, p. 21-24, 1996. 